\title{
Decolonising Neo-Liberal Innovation: using the Andean philosophy of 'Buen Vivir' to reimagine innovation hubs
}

\author{
Andrea Jimenez ${ }^{1}$ and Tony Roberts ${ }^{2}$ \\ ${ }^{1}$ University of Sheffield, Sheffield, UK \\ a.jimenez@sheffield.ac.uk \\ ${ }^{2}$ Institute of Development Studies, University of Sussex, Brighton, UK \\ t.roberts@ids.ac.uk
}

\begin{abstract}
Innovation is increasingly portrayed as central to social and economic development. Models of innovation from the global North are often applied uncritically in the global South. Doing so may unwittingly silence indigenous knowledge, ways of knowing, and cultural values. Santos (2014) has argued that this form of epistemic violence is committed when actors from the global North are insufficiently mindful of 'Epistemologies of the South'. Neither Santos nor the authors of this paper believe that there is nothing of value to be learned from the global North - only that there is as much to be learned from the global South - and everything to be gained from a skillful combination of different ways of knowing. This theoretical paper proposes a future line of research to examine in what ways Epistemologies of the South might inform innovation processes to produce different outcomes. We use the example of innovation hubs and although we might have used the philosophies of Ubuntu from Southern Africa or Swaraj from India, in this paper we use the lens of Buen Vivir (living well) from Andean and Amazonian communities in South America to suggest that another innovation is possible.
\end{abstract}

Keywords: Innovation, Epistemologies of the South, Decolonising, Buen Vivir.

\section{Introduction}

Over recent decades we have seen income inequality increased in every region [1]. The number of African people living in poverty in 2018 is now 113 million more than it was in 1990 [2], and the dominant economic development model has proven to be ecologically unsustainable [3].

Innovation has variously been proposed as a way to reduce poverty, inequality and climate change [4]; [5]. In the Sustainable Development Goals innovation is referred to as a 'crucial driver of economic growth and development' and is considered sufficiently important to feature explicitly in six different SDG $\operatorname{targets}^{1}[6]$. In the research discourse innovation is often presented as an ideologically neutral 'technical fix’ divorced from any industry interests or political aims [7] [8]. Despite attempts to portray innovation as politically neutral, several decades of evidence from Science and Technology Studies (STS) research demonstrates that innovation processes generally reflect the dominant political and ideological values of innovators or societies in which they lived [9].

1 Innovation in included in SDG targets 8.2, 8.3, 9.5, 9b, 17.6 and 17.8. 
From a development perspective innovation is defined as applying new tools or processes to address development challenges and unmet needs [10]. To achieve this, the World Bank, United Nations Development Programme (UNDP), the United Nations High Commissioner for Refugees (UNHCR) and UNICEF have been establishing their own Innovation Labs. Moreover, the Global Innovation Fund ${ }^{2}$, the Global Challenges Research Fund and a range of other funding agencies provided funding to a wide range of innovation initiatives, including more than 300 'innovation hubs' in Africa alone [11].

\section{Innovation Hubs}

Innovation hubs are places where technology entrepreneurs, experts and enthusiasts meet to collaborate on their latest apps, platforms and development projects [12]. The authors' prior experience of long-term research based in innovation hubs gave rise to our research interest in whether hubs in the global South were too closely modelled on the global North template of Silicon Valley start-up culture, and if so whether this might lead to a lost opportunity to nurture indigenous approaches to innovation, as well as the risk of importing political and ideological values that drown out and silence local values and interests (See [13]; [14]). Other authors have been exploring similar aspects (for example, [15]).

Innovation hub events in the global South often feature 'masterclasses' led by individuals or featuring methods from the global North - sometimes hosting venture capitalists or famous entrepreneurs such as Mark Zuckerberg [16]. Often, the hackathons and pitching events that they host, assess innovations in terms of whether they are patentable, monetisable, or scalable, and calculate the value of innovations as dollar return on investments. From this perspective technology and innovation hubs can be interpreted to be sites where the goal and measure is to become as much like the Silicon Valley (USA) as possible. This is evidenced by the label of Silicon Savannah, used to characterise the technology and innovation ecosystem in Kenya [17], thereby assimilating previous forms of mechanistic modernisation theory [18].

This paper addresses the concern that if innovation approaches from the global North are applied uncritically in the global South, they may unwittingly subordinate indigenous knowledge, ways of knowing, and cultural values. This paper also makes the political and ecological argument that smuggling in growth-orientated neo-liberal development under the guise of innovation can be considered to be both neo-colonial as well as environmentally unsustainable. We use innovation hubs as an example of innovation processes in this paper because of our prior experience but hope that researchers and practitioners with other innovation experience will find resonance in other innovation settings. In this paper we remain with de Sousa Santos [19] example of Buen Vivir (living well) from South America in order to argue that another innovation is possible.

\footnotetext{
2 https://globalinnovation.fund/
} 


\section{Literature Review}

Innovation is 'the process by which novelty is taken up and circulated in the public sphere' [20]. Scholars, practitioners and policy makers have focused on ways in which innovation can be improved, enhanced and diffused [21]. In the innovation for development literature authors often argue that innovation is central to economic growth and thus crucial to development [22] and innovation is promoted as a development mechanism [23]. Pansera \& Owen [8] argue that innovation for development approaches embody distinctive political dimensions, cultural values and normative worldviews, and that they often leave unproblematized implicit neo-liberal, individuated and market-oriented approaches. The National Systems of Innovation (NSI) approach, for instance, has been a dominant discourse [24] emphasising the interrelation of different actors as fundamental to strong national innovation ecosystems. In this process, authors have often focused on economic actors and institutions, exploring the role of NSI in competitive advantage and economic growth. More recently, there has also been a proliferation of innovation concepts that attempt to describe phenomena happening in resource-constrained environments to explain innovation phenomena. Terms like 'frugal innovation, 'reverse innovation', 'pro-poor innovation', 'Bottom of the Pyramid (BOP) innovation', 'grassroots innovation', 'inclusive innovation' are most popular in the literature [25]. Although these concepts have expanded our understanding of innovation by focusing on the marginalised in society, they tend to still be framed within the dominant economic discourses albeit with some better focus on inclusivity. In this sense, even though these concepts advance our understanding of innovation in the global South, they still operate within a neoliberal paradigm.

Most innovation research is framed within an economic system that perpetuates growth [26] despite irrefutable evidence that perpetual growth is not possible on a finite planet [27]. The Sustainable Development Goals fail to address this inconvenient truth when they set continued growth as a key Global Goal (SDG8) and commit the international community to building innovation capacity (SDG 17) in order to achieve it. The next section shows how the underlying logic of neo-liberalism demands requires perpetual innovation in pursuit of the unattainable goal of perpetual growth.

\section{$2.1 \quad$ Neoliberalism}

Although there is no agreed definition of neo-liberalism, there is consensus that it "is built on deregulation, liberalization, privatization and ever tighter global integration" [28]. In this paper we rely on the more expansive definition of Harvey [29] that neoliberalism is an hegemonic ideology or a theory of political economy discourse that 'proposes that human well-being can best be advanced by liberating individual entrepreneurial freedoms and skills within an institutional framework characterized by strong private property rights, free markets, and free trade'. In this respect, innovation is framed as key in improving efficiency and driving economies. 
The neo-liberal paradigm also holds an underlying notion that economic liberalisation (freedom of market and trade) is a necessary step towards individual freedom. In this respect, Bourdieu [30] argued that the neoliberal project was 'a programme of the methodical destruction of collectives' (pp. 95-96). This implies that individuals have moral priority and '[...] may not be limited by the community, common good or interest' [31]. Neoliberalism then, encourages the individualisation of the social and the collective [32].

In neo-liberal theory, economic growth is portrayed as self-evidently desirable [33], driven by the dynamism of individual entrepreneurs and by creative gales of technological destruction. Growth itself constitutes the goal of neoliberalism, overriding concerns for social equity or environmental sustainability [34]. Despite neoliberalism being founded on the idea of freedom, the globalisation of the neoliberal project demonstrated its imposition in countries of the global South through coercive programs of structural adjustments [18]. This took the form of 'modernisation' as the enforced adoption and imitation of economic and ideological approaches copied from 'developed countries'. The social, cultural, and structural forms stemming from Western societies were idealised and compared to the 'traditional' societies, seen as backward and as such in crucial need of modernisation [35].

One devastating effect of this modernisation process has been the exploitation of natural resources to industrialise and urbanise societies. To counteract the negative consequences of climate change, there have been attempts to manage the environment without stopping growth, with the introduction of concepts like 'green economy' and 'sustainable development' [3]. Furthermore, in the current era there has also been an attempt to step away from mechanistic modernisation by highlighting economic growth in Southern contexts, with examples like the rise of Asia and the increasing influence of the East in the world. However, it other contexts like South America and sub-Saharan Africa there is still the contentious push for recognising their own voice, given the pressure of modernisation patterns still experienced [3].

\subsection{Neoliberal innovation for development}

This dominant neoliberal paradigm is also framing the way innovation for development is conceptualised and practiced. There are two main characteristics of this framing. Firstly, there is a strong emphasis on funding disruptive innovation to drive economic growth [36]. As such, innovation is often framed from an individualistic dimension, embracing the ideal entrepreneur as seeking profit maximisation. Secondly, innovation in the South is expected to mirror models and concepts from the North, following a path of uncritical modernisation. This amplifies the dominant worldview at the expense of other voices.

Rather than continuing to uncritically adopt and adapt neo-liberal concepts and theories of innovation from the Global North, this paper argues that it is important to also explore alternative conceptions of innovation, taking into account indigenous knowledges and values from the Global South. The next section details alternative frameworks known as epistemologies of the South [19]. 


\section{Epistemologies of the South}

In this section we introduce the overarching notion of 'Epistemologies of the South', this will help to explain how and why a concept like Buen Vivir becomes relevant in our understanding of development and subsequently, innovation. Ever since colonial times, certain kinds of knowledges have been privileged as valid, consequently prioritising certain kinds of activities, and by extension have delegitimised and subordinated others [37]. This epistemic dimension has been referred by Aníbal Quijano [38] as the "coloniality of power", and later described by Mignolo [39] as "the less visible side of modernity" (As cited in Bruman 2017, my translation). Moreover, this epistemological dimension has followed through to current context, as explained by Tuhai-Smith [37], '[...] although in the reframed discourse of globalisation.' (p.92).

This practice, of imposing a foreign knowledge as valid and diminishing indigenous knowledges is labelled by postcolonial scholars such as Spivak [40] as 'epistemic violence', which actively obstructs and undermine non-Western methods or approaches to knowledge as the Other. As explained by Theo [41], epistemic violence happens when '[...] theoretical interpretations regarding empirical results implicitly or explicitly construct the Other as inferior or problematic, despite the fact that alternative interpretations, equally viable based on the data, are available' (p.298). Freire refers to a similar phenomenon as 'cultural invasion', where '[...] invaders penetrate the cultural context of another group, in disrespect of the latter's potentialities, they impose their own view of the world upon those they invade and inhibit the creativity of the invaded by curbing their expression' [42]. At the heart of this understanding of imposing Western knowledge into other contexts is the notion that such type of knowledge has become hegemonic and dominant, and other types of knowledges are subverted and portrayed as inferior.

It their substantive senses, epistemologies of the South replace the dominance of Western ideas by a notion of 'interculturality', from which Western knowledge is not rejected but seen as one among many options [43]. As a way to do this, Santos, suggests we engage in a plural dialogue between different systems of knowledge and between different epistemologies, without pre-established hierarchies [19].

The next section introduces one epistemology of the global South, which guides the framework for this analysis.

\subsection{Buen Vivir}

Buen Vivir is a discursive 'work-in-progress' resulting from the cross-pollination of traditional indigenous knowledges and the interpretive and articulating work by scholars and political leaders [44]. Indigenous ontologies and traditions do not involve an idea of progress as a linear unfolding of history, nor do they perceive that wellbeing is associated with ideals of individuation where humankind is separate from nature [45]. Rather they see the world as a plurality of stories happening alongside each other, with no single totalising narrative. Buen Vivir scholars and activists suggest that we reframe our understanding of the world from the existence of a 'uni- 
verse' to a 'pluri-verse', which is defined as “[...] understanding that reality is constituted not only by many worlds, but by many kinds of worlds, many ontologies, many ways of being in the world, many ways of knowing reality, and experimenting those many worlds" [45].

Scholars saw an alternative to neoliberalism and the growth paradigm that was characterising the way development was implemented in Latin America, enhancing inequalities and destroying ecosystems. The consequence of discussions between indigenous communities and scholars has led to a definition on Buen Vivir as a concept under construction, shifting away from the mind-set of production and consumption and against growth-based development [46]. Instead, Buen Vivir values aspects that benefit the community, with strong environmentally-oriented ideas. This suggests that some indigenous communities would prioritise values of collectivism, environmental justice and reciprocity.

Buen Vivir introduces three novel ideas: first, it is elaborated by peoples who have been historically marginalised [46]; second, well-being is not conceived in its individualistic Western sense, but rather in the context of a community [47]; and third, the natural environment can be conceptualised as a subject of rights and therefore cannot be subjected to market logics [48]. In more practical terms, Buen Vivir suggests a transition from a capitalist mode of production to a social and communal economy. This economy would take consideration for the constraints of the environment and where surpluses would be invested back into the community [49].

Attempts to include Buen Vivir into policy have been proposed, even though they not existed without challenges and contradictions [50]. For instance, Buen Vivir was introduced to the Ecuadorian Constitution during the government of president Rafael Correa in 2007, mentioned at least 25 times in the Constitution and subsequently integrated into 3 national development plans [51].

Authors have discussed various challenges contradictions of this experience. Williford [51] summarises them into a continued reliance on extractivist methods, the centralising of power and silencing of indigenous voices, and the shift from depending on the World Bank and IMF to China. However, authors have also highlighted the positive effects this experience has, including rejecting a neoliberal definition of development, strengthening regional ties in Latin America and visibilising the voices of indigenous peoples. The experience of Ecuador demonstrated that Buen Vivir can become co-opted as a discourse, without much change. Authors explain that the structural preconditions for the implementation of Buen Vivir at a nation level are not in place yet [52]. However, other authors argue that the way in which Buen Vivir has been incorporated in government initiatives is dialogical, and as such the implications should be measured by its contribution to destabilising dominant existing cognitive and cultural templates, and by, most importantly, showing that it is possible to explore alternative ways of living than the neoliberal one suggests [53] [3].

Buen Vivir resembles aspects from other concepts developed elsewhere. For instance, it has been related to the concept of degrowth, developed mainly by European scholars to critique the growth paradigm, suggesting instead values of 
'sharing', simplicity, conviviality and care [26]. Furthermore, they also share commonalities with indigenous concepts that have been historically part of other cultures in the Global South. For instance, Swaraj, developed in India which refers to self-reliance and self-governance [53] [3] and Ubuntu in Africa, which emphasises human mutuality [54]. Even though they stem from different contexts and are based on different traditions, scholars have demonstrated the similarities of such concepts in terms of their rejection to individualism and growth without consideration of the environment. Furthermore, they also share in common the fact that they often arise from traditionally marginalised groups [3]. In this sense, Buen Vivir, as an epistemology of the South, recognises the need to account for the diversity of the world and the urge for more intercultural understanding, although it critiques the viewpoint that theories produced in the global North are best equipped to account for the social, political and cultural realities of the South [19].

In summary, Buen Vivir is a work-in-progress presented as an alternative to development. It does not aim to become a dominant, hegemonic ideology because it is based in the recognition of multiple perspectives coexisting. It proposes that we replace values of individualism and growth, without consideration of the environment, with values of solidarity, reciprocity, complementarity, harmony and interdependence.

\section{$4 \quad$ Analysis}

Having introduced the concept of Buen Vivir as an alternative to the dominant neoliberal view, this section will establish the distinctive elements of neoliberal and Buen Vivir philosophy; to then describe what features innovation would have under each paradigm. We distinguish three themes emerging from our review of both paradigms, the ontology, concerned with the nature of reality and what there is to know about the world; the ideology, understood as distinctive set of discursive themes and standpoints and finally, ethics, as what is considered to be good and valued. We recognise that these elements form part of a complex reality, yet for analytical purposes they are being separated here.

\subsection{Neoliberal vs Buen Vivir}

Table 1 presents a summary of the key aspects of a neoliberal innovation paradigm in contrast with a Buen Vivir innovation paradigm. In the neoliberal paradigm, the ontology functions around an individualistic worldview, that is the idea of individual freedom to set and pursue one's own goals. This type of individualism 'hence puts a claim on the nature of human beings, on the way they live their lives and their relation to society' [55] (p.17). Furthermore, linked to the notion of individualism is the understanding that it is individual economic interests and overall economic growth. By adopting this worldview, material resources exist in function to individuals, and not the other way around. As a consequence, the environment is perceived to be at the service of pursuing individual freedom and therefore subsumed to an individual's path to achieving his or her own goals. 
Given that this is the worldview adopted, then anything that benefits individuals constitutes part of the ideology. The environment becomes a commodity, that has economic value and that is subordinated to the advancement of human interests. This means that it is imperative to produce benefits for individuals in their quest to satisfy what they perceive as needs and desires. Furthermore, what is considered as ethical is that people perceive 'freedom' to achieve their own goals, being them the primary point of concern. If the environment is an impediment for one's own perception of wellbeing, then it is subordinated, commodified, transformed and in some cases destroyed to achieve individual success.

By contrast, from a Buen Vivir's ontological perspective, the individual is only a part of a collective, of species, non-human and of different peoples in other contexts. In this sense, it is not possible to separate the individual from its interdependence with others, because everybody and everything is connected. This means that it is not possible to subordinate the environment and perceive it as a commodity.

This way of looking at the world is translated into an ideology that relies on strong environmental ethics, collective benefits and a strong spiritual and affective rationality. The main logic therefore looks out for what process would provide a better outcome for everyone, rather than an individual. It also rejects a market-based logic that may have detrimental effects in the environment and instead supports models that would benefit it. In this sense, it would support alternative ways to being, producing and obtaining resources, one that first and foremost is in harmony with the environment and with others. It would also imply that the earnings of a particular resource would be shared amongst everyone.

Table 1. Neoliberal Paradigm vs Buen Vivir Paradigm (Source: authors)

\begin{tabular}{|c|c|}
\hline Neo-Liberal & Buen Vivir \\
\hline Ontology & Ontology \\
\hline Individual (others out there) & Collective, connected, related, \\
\hline Independent & Interdependent, mutuality \\
\hline Environment (out there) as & Environment as part of us \\
\hline resource & Ideology \\
\hline Ideology & Needs-based cooperativism \\
\hline Market-based capitalism & Collective benefits \\
\hline Private profit & Logic of shared interests \\
\hline Market logic & Environmental as part of us - \\
\hline Environment as private resource & Pachamama \\
\hline $\begin{array}{l}\text { Goal of economic growth } \\
\text { Ethics }\end{array}$ & Goal of collective living well (de- \\
\hline Individual self-interest & Ethics \\
\hline Distribution according to means & Collective shared interest \\
\hline & Distribution according to needs \\
\hline
\end{tabular}




\subsection{Neoliberal Innovation vs Buen Vivir Innovation}

Following the neoliberal paradigm, innovation adopts an individualistic form, framed around the notion of individual wellbeing. Stories of individual 'innovators' becoming billionaires would be valued as a heroic achievement. An innovation would be considered a novelty that can be patented or privatised, and there is a need to promote more development of such novelties. Finally, scaling would be appropriate to reduce costs and promote value for money.

By following the Buen Vivir paradigm, then innovation takes a collective form that would support mutual respect for each other and the natural world. Collective processes would be valued and innovation would be effectively benefiting the commons rather than individuals. Appropriateness would be valued over the costs and it would aim for producing positive effects for as many as possible.

\subsection{Neoliberal Innovation Hubs vs Buen Vivir Innovation Hubs}

As already mentioned, our previous research centred in understanding the role of innovation hubs in development. In such work we have argued that there is an expectation that hubs will promote economic growth. In this paper we present some characteristics of a hub, framed in a neoliberal context.

A neoliberal innovation hub would prioritise innovations that are patentable, for instance mobile applications that can be monetised. Furthermore, it will seek to promote innovations that are investable, to attract angel investors or other types of investors. It will seek to do this in a dynamic and efficient way, and often host hackathons and events that seek to develop cool/interesting ideas. As a result, innovations that are perceived to have monetary value would be framed to scale.

In contrast, a Buen Vivir innovation hub, if it ever existed, might reasonably be expected to have a strong focus on innovation for collective well-being. Such hubs might emphasise collaborative process and prioritise inclusive innovation. In this sense, rather than focusing on whether an innovation will be scalable and investable, it would prioritise innovation that is environmentally just, that include all voices and that contributes to living well, rather than making a profit. It is important to note that, just as the aforementioned example of Ecuador, an attempt to integrate Buen Vivir into practice will be confronted by several tensions and contradictions. Here, we do not intend to assume that this will be a smooth process, rather a dialectical one. More research is needed to see the feasibility of this.

\section{Conclusion}

In this paper we counterposed existing neo-liberal innovation with an imagined alternative approach to innovation informed by the values of Buen Vivir. We do so because we see value in imagining innovation otherwise and in reflecting the worldviews of the people that they are intended to benefit. Furthermore, we explored alternatives around innovation which pushed a neoliberal agenda (of which uncontrolled growth is one element). 
By adopting this alternative perspective, we have attempted to provide a starting point for problematizing neoliberal innovation and opening a thought-space for considering new possibilities. We have suggested that another innovation, one informed by the values and worldview of Buen Vivir might prioritise collective, ethical, ecological and culturally sensitive innovation that contributes to the common well-being.

We recognise how difficult it would be to actually transform the neoliberal ideas around innovation and development. The example of Ecuador show that we are far from achieving a real transformation with the adoption of indigenous knowledges. This makes us wonder, as [51] (p. 110) asks, "Is maintaining western notions of development in practice while investing in the social sector a first step in the process of moving away from the modernist paradigm? Or is the commitment to buen vivir principles in this particular case only superficial?" The answers to these questions should encourage future research.

Future research should put this in action to see in what ways innovations/tech hubs can produce values of environmental ethics, collective benefits and a strong spiritual and affective rationality, thereby promoting an alignment with such worldviews. The inclusion of indigenous viewpoints (like Buen Vivir) should not just be instrumental, it should be epistemological and ontological. In our view, the Western (neoliberal) approach to innovation represents only one possible approach among others, and we should therefore accept the possibility of a plurality of legitimate paradigms around innovation and its impact in our societies. In this sense, in a world with increasing inequality, huge environmental and ecological risks, 'Is another innovation possible?'.

\section{References}

1. World Inequality Lab https://wir2018.wid.world/ (2017)

2. World Bank datatopics.worldbank.org/sdgatlas/archive/2017/SDG-01-no-poverty.html (2017).

3. Kothari, A.; Demaria, F \& Acosta, A. Buen Vivir, Degrowth and Ecological Swaraj: Alternatives to sustainable development and the Green Economy. Development, 2014, vol. 57, issue 3-4, 362-375. (2016).

4. Cozzens, S. \& Sutz, J. Innovation in informal settings: reflections and proposals for a research agenda, Innovation and Development, 4(1), 5-31, (2014).

5. Pansera, M. Frugal or Fair? The Unfulfilled Promises of Frugal Innovation. Technology Innovation Management Review. 8 (4), 6-13, (2018).

6. UNDP (2018) http://www.undp.org/content/undp/en/home/sustainable-developmentgoals/goal-9-industry-innovation-and-infrastructure.html

7. Ferguson, J. The Anti-politics Machine: Development, Depoliticization, and Bureaucratic Power in Lesotho. Cambridge University Press, Cambridge (1990).

8. Pansera, M.; Richard, O. Framing inclusive innovation within the discourse of development: Insights from case studies in India. Research Policy, Vol. 47, No. 1, 47(1), 2018, p. 23-34.

9. Mackenzie, D. and Wajcman, J. (1985) (eds) The Social Shaping of Technology, Milton Keynes, Open University Press.

10. World Bank (2015) https://blogs.worldbank.org/voices/what-are-innovation-labs-andhow-can-they-improve-development-0 
11. World Bank (2016) http://blogs.worldbank.org/ic4d/importance-mapping-tech-hubsafrica-and-beyond

12. Jiménez, A. \& Zheng. Y. Tech hubs, innovation and development, Information Technology for Development, 24:1, 95-118, (2018).

13. Roberts, T., Critical Agency in ICT4D, Doctoral Thesis, Royal Holloway University of London, (2015).

14. Jiménez, A., and Y. Zheng. 2017a. "A Spatial Perspective of Innovation and Development: Innovation Hubs in Zambia and the UK." In Information and Communication Technologies for Development. ICT4D 2017. IFIP Advances in Information and Communication Technology, edited by J. Choudrie, M. Islam, F. Wahid, J. Bass, and J. Priyatma, Vol. 504. Cham: Springer.

15. Avle, S., Lindtner, S., and Williams, K. How methods make designers. In Proceedings of the SIGCHI Conference on Human Factors in Computing Systems (CHI '17), 472482. (2017)

16. Friederici, N. Hope and Hype in Africa's Digital Economy: The Rise of Innovation Hubs. In M. Graham (Ed.), Digital Economies at Global Margins. Boston, MA, USA: MIT Press. (2018)

17. Gitonga, J.: The past, present, and future of the 'Digital Nyika': how to fix an aircraft in flight. In: Ndemo, B., Weiss, T. (eds.) Digital Kenya: An Entrepreneurial Revolution in the Making, pp. 13-23. Palgrave Macmillan, London (2017).

18. Escobar, A. Encountering Development: The Making and Unmaking of the Third World (2nd ed.), Princeton University Press, Princeton (2012).

19. De Sousa Santos. B. Epistemologies of the South. Routledge. New York (2014).

20. De Saille, S. \& Medvecky. F. Innovation for a steady state: a case for responsible stagnation, Economy and Society, 45:1, 1-23 (2016).

21. Srinivas, S., \& Sutz, J. Developing countries and innovation: Searching for a new analytical approach. Technology in Society, 30(2), 129-140. (2008).

22. Williams, L. D. A., \& Woodson, T. S. The future of innovation studies in less economically developed countries. Minerva, 50(2), 221-237 (2012).

23. Krause, U. Innovation: The new Big Push or the Post-Development alternative?, Development 56(2), 223-2 (2013).

24. Lundvall, B.-Å National innovation systems - analytical concept and development tool. Industry \& Innovation, 14(1), 95-119 (2007).

25. Zeschky, M., Winterhalter, S., and Gassmann, O., From Cost to Frugal and Reverse Innovation: Mapping the Field and Implications for Global Competitiveness, ResearchTechnology Management, Vol 57 (4) (2015)

26. D’ Alisa, G.; Demaria, F.; Kallis, G. Degrowth. Routledge. New York. (2015).

27. Jackson, T. Prosperity without Growth: economics for a finite planet, Oxon, Routledge. (2011).

28. Crotty J. Structural contradictions of the global neoliberal regime. Review of Radical Political Economics 32: 369 -78 (2003).

29. Harvey, D. A Brief History of Neoliberalism. Oxford: Oxford University Press (2005)

30. Bordieu, P. The Essence of Neoliberalism. Le Monde Diplomatique. https://mondediplo.com/1998/12/08bourdieu (1998).

31. Ikuenobi, P. African communal basis for autonomy and life choices. Developing World Bioethics (2017).

32. Ferge, Z. The changed welfare paradigm: The individualization of the social, Social Policy \& Administration, 31, 1: 20-44 (1997). 
33. Türken, S., H. E. Nafstad, R. M. Blakar, and K. Roen. Making Sense of Neoliberal Subjectivity: A Discourse Analysis of Media Language on Self-development. Globalizations 13 (1): 32-46 (2016).

34. Friman, E. No Limits: The 20th Century Discourse of Economic Growth. PhD Theis, Department of Historical Studies. Umeå: Umeå University (2002).

35. Makki, F., Reframing development theory: the significance of the idea of uneven and combined development. Theory and Society, 44(5), pp.471-497 (2015).

36. Ojomo, E. Disruptive innovation: The most viable strategy for economic development in Africa. Blog: http://blogs.worldbank.org/africacan/disruptive-innovation-the-mostviable-strategy-for-economic-development-in-africa (2016).

37. Tuhiwai Smith, L. Decolonizing Methodologies: Research and Indigenous Peoples, Zed Books, London (1999).

38. Quijano, Aníbal. Colonialidad y modernidad/racionalidad.Perú indígena,29:11-20 (1991).

39. Mignolo, W. I am where I think: epistemology and the colonial difference. Journal of Latin American Cultural Studies: Travesia 8(2): 235-245 (1999).

40. Spivak, G.C. Can the subaltern speak? Speculations on widow sacrifice', Wedge, 7/8 (Winter/Spring). (1985)

41. Theo, T. What is Epistemological Violence in the Empirical Social Sciences? Social and Personality Psychology Compass 4/5 295-303, (2010).

42. Freire, P. Pedagogy of the oppressed. London: Penguin Books. (1970).

43. Gudynas, Eduardo. Buen vivir: germinando alternativas al desarrollo. America Latina en Movimiento 462:120 (2011).

44. Acosta, A., El Buen Vivir en el camino del post-desarrollo. Una lectura desde la Constitución de Montecristi, Fundación Friedrich Eber, FES-ILDIS, Quito (2010)

45. Querejazu, A. Encountering the Pluriverse: Looking for Alternatives in Other Worlds Revista Brasileira de Política Internacional , 59(2) (2016).

46. Giovannini, M. Indigenous community enterprises in Chiapas: a vehicle for buen vivir? Community Development Journal, 50, 71-87 (2015).

47. Huanacuni, F. Buen Vivir/Vivir Bien. Coordinadora Andina de Organizaciones Indigenas (CAOI). Lima (2010)

48. Mamani Ramírez, P. Qamir Qamaña, dureza de " estar estando " y dulzura de " ser siendo". Disponible en: http://www.gritodelosexcluidos.org/media/uploads/ vivirbien.pdf (2011)

49. Prada-Alcoreza, R. Buen Vivir as a model for State and Economu, in 'Mas alla del desarrollo’ by Fundación Rosa Luxemburg/Abya Yala Ediciones in November (2011).

50. Radcliffe. S. Development for a postneoliberal era? Sumak kawsay, living well and the limits to decolonisation in Ecuador. Geoforum 43, 240-249 (2012).

51. Williford, B. Buen vivir as policy: challenging neoliberalism or consolidating state power in Ecuador. Journal of World-Systems Research 24(1) (2018).

52. Beling, A., Vanhulst, J. Demaria, F., Rabi, V., Carballo, A., \& Pelenc, J. Discursive synergies for a "great transformation" towards sustainability: pragmatic contributions to a necessary dialogue between human development, degrowth, and Buen vivir, Ecological Economics, 144, 304-313 (2018).

53. Kothari A Radical ecological democracy: a path forward for India and beyond. Great transition. (2014)

54. Msila, V. Decolonizing knowledge for African's Renewal: Examining African Perspectives And Philosophies (2017) 
55. Robeyns, I. The Capability Approach: a theoretical survey, Journal of Human Development, 6(1), 93-117. (2005). 